\title{
Effect of pulse sprout spray as a foliar nutrition to enhance seed yield and quality in barnyard millet (Echinochloa frumentacea I.)
}

\author{
N. Nandha Kumar \\ Department of Seed Science and Technology, Tamil Nadu Agricultural University, Coimbatore \\ (Tamil Nadu), India \\ S. Lakshmi \\ Department of Seed Science and Technology, Tamil Nadu Agricultural University, Coimbatore \\ (Tamil Nadu), India

\section{S. Sathya*} \\ Department of Seed Science and Technology, Tamil Nadu Agricultural University, Coimbatore \\ (Tamil Nadu), India \\ ${ }^{*}$ Corresponding author. E. mail: sathya.agri03@gmail.com
}

\section{How to Cite}

Kumar, N. N. et al. (2020). Effect of pulse sprout spray as a foliar nutrition to enhance seed yield and quality in barnyard millet (Echinochloa frumentacea I.). Journal of Applied and Natural Science, 12(3): 394 - 400. https://doi.org/10.31018/jans.v12i3.2333

\begin{abstract}
Millets are rich in valuable nutrients such as carbohydrates, proteins, dietary fibre, minerals and vitamins. The uninterrupted and disproportionate use of chemical fertilizers over a longer period has resulted in deterioration of soil health and reduced yield. Foliar spray is a very easy way to supply valuable nutrients to plants. With this background, an experiment was conducted to see the effect of pulse sprout extract spray as a foliar spray on the seed crop Barnyard millet (Echinochloa frumentacea L.). The seed crop given foliar treatment with $2 \%$ horse gram pulse sprout extract spray recorded higher growth attributes namely plant height $(172.8 \mathrm{~cm})$, total chlorophyll content $(1.560 \mathrm{mg} / \mathrm{g})$ and yield attributes viz., seed yield per plant $(26.5 \mathrm{~g})$, seed yield per plot $(2.54 \mathrm{~kg})$, seed yield per hectare $(2506 \mathrm{~kg}), 1000$ seed weight $(3.28 \mathrm{~g})$, quality parameters viz., germination (89\%), vigour index (2461) and biochemical parameters of resultant seeds in both kharif and rabi seasons. The crop given with foliar nutrition of $2 \%$ horse gram sprout extract spray showed a low number of days to flower initiation ( 45 days) and $50 \%$ flowering (54 days) when compared to control followed by $2 \%$ cowpea sprout extract. Hence it was hypothesized that application of the nutrient extract from the sprouted pulses in the form of foliar spray would enable better crop growth and productivity of Barnyard millet.
\end{abstract}

Keywords: Barnyard millet, Foliar spray, Horse gram, Cowpea sprout extract

\section{INTRODUCTION}

Millets occupy a vital position in providing nutrition to the ever-growing population of the world. Small millets are highly energetic and supply nutritious foods comparable to other cereals (Himanshu et al., 2018). They are particularly low in phytic acid and rich in dietary fibre, iron, calcium and vitamin B (Sujatha et al.,2013). Barnyard millet (Echinochloa frumentacea L.) is also known as sawa millet. It is well adapted to low and moderate rainfall areas $(500-700 \mathrm{~mm})$ due to its early maturity character. It is an excellent source of dietary fibre $(13 \mathrm{~g} / 100 \mathrm{~g})$ with good amounts of soluble (4.66 $\mathrm{g} / 100 \mathrm{~g}$ ) and insoluble $(8.18 \mathrm{~g} / 100 \mathrm{~g})$ fractions and fair source of highly digestible $(81.13 \mathrm{~g} / 100 \mathrm{~g}$ digestibility) protein (Veena et al., 2005).

Over the last decade, scientists were working more towards the determination of the biological value of the nutritional sprouts (Penas et al., 2008). Organic farming is not mere non-chemical in agriculture, but it is a system of farming based on an integral relationship in nature (Jayanthi et al., 2013). In order to get the maximum productivity, the mother plants should be added with nutrients using the foliar application. This will reduce the loss through absorption, leaching and other process associated with soil uses (Geetharani et al., 2008). Foliar application is credited quick and efficient utilization of nutrients (Abid et al., 2019).

Sprouting of grains for a limited period leads to increased activities of hydrolytic enzymes, improvement in the contents of essential amino acids, total sugars, Bgroup vitamins and decrease in dry matter, starch and antinutrients (Saira et al., 2011). The foliar spray with horse gram sprout extract and cowpea sprout extract at $3 \%$ level could record the highest germination, vigour 
and yield parameters when compared to control (dry seeds) and water-soaked seeds in rice (Vijayalakshmi, 2009), cotton (Sakthivel, 2010) and green gram, black gram (Gomathi, 2011). The present work was conducted on barnyard millet ( $E$. frumentacea L.) to study the effect of pulse sprout extract spray to improve the seed quality and seed yield.

\section{MATERIALS AND METHODS}

Field experiments were carried out at Department of Seed Science and Technology, Agricultural College and Research Institute, Madurai on seed crop of in Barnyard millet (E. frumentacea L.) during kharif and rabi 2016-17, to determine the effect of pulse sprout extract spray as mother crop nutrition.

Pulse sprout milk was extracted by soaking the horse gram and cowpea seeds for $12 \mathrm{~h}$ followed by incubation of $12 \mathrm{~h}$ in a wet cloth to permit sprouting of seeds. The sprouted seeds were ground in a mixer - grinder after adding ice-cold water @ 1:1 ( $/$ / ml) and squeezed through cloth to extract the milk of 100 per cent concentration (Jayanthi, 2008).

Treatment details: The three concentrations viz; 1,2 , $3 \%$ horse gram sprout extract and 1, 2, 3\% cowpea sprout extract were explored as a foliar spray to field trials for evaluating their effect on crop growth and productivity of Barnyard millet (E. frumentacea L.) var.CO (KV)2. T1 - Control; T2 - Cowpea sprout extract 1\%; T3 - Cowpea sprout extract 2\%; T4 - Cowpea sprout extract 3\%; T5 - Horse gram sprout extract 1\%; T6 - Horse gram sprout extract 2\% ; T7 - Horse gram sprout extract $3 \%$; T8 - DAP $2 \%$. The foliar spray was applied in three stages viz; 60 Days after sowing, 75 Days after sowing and 90 Days after sowing.

Layout of the experiment: Two field trials were conducted at S1 - Kharif 2016; S2 - Rabi 2016-17 with three replications and a plot size of $3 \times 3 \mathrm{~m}$ and $4 \times$ $3 \mathrm{~m}$. The following observations were made on crop growth and yield factors.

Growth parameters: Plant height was measured from ground level to tip of the leaf at active tillering, flowering and harvest stages, and the mean height was expressed in $\mathrm{cm}$.

Total chlorophyll content was computed using the following formula (Arnon, 1949) and expressed as mg g-1 of a fresh leaf (Yoshida et al., 1976). The optical density of the extract was read in an ELICO UV-VIS Spectrophotometer (Model SL-159).

Total chlorophyll $=\frac{\text { OD value at } 652 \times 1000 \times \mathrm{V}}{34.5 \times \mathrm{W} \times 1000} \times 100$

Where,

$\mathrm{V}=$ Final volume of acetone extract; $\mathrm{W}=$ Fresh weight of sample in gram $(\mathrm{g})$
The number of days taken for first flowering and for $50 \%$ flowering was assessed in five plants selected at random in each replication, and the mean value was expressed in days.

Yield attributes: Seeds obtained from all the five randomly tagged plants were weighed after drying to $10 \pm$ 0.5 per cent moisture content, and seed yield per plant was expressed in $\mathrm{g}$. Seeds obtained from the net plot area of each treatment were dried, cleaned and weighted and Seed yield per plot expressed as $\mathrm{kg}$ The seed yield recorded in each plot was computed for hectare yield and expressed in $\mathrm{kg} / \mathrm{ha}$.

Seed quality parameters: One thousand seeds from each treatment were chosen at random, and their weight was recorded on electronic balance as per ISTA procedure (Anonymous, 1999), and an average of 1000 seed weight was expressed in g. Germination test was conducted by following the procedure outlined in ISTA (2012) by roll towel method with 8 replication 400 seeds under controlled conditions in which $25 \pm 2^{\circ} \mathrm{C}$ and $95 \pm 2 \%$ of temperature and $\mathrm{RH}$, respectively were maintained. On $10^{\text {th }}$ day, no. of normal seedlings were counted and expressed as a percentage. Ten normal seedlings were selected randomly, and root length (cm) was measured from the collar region to the tip of the primary root and shoot length $(\mathrm{cm})$ from the collar region to the tip of primary leaves. Same seedlings used for growth measurement were placed in a paper cover, shade dried for $24 \mathrm{~h}$ and then kept in a hot air oven maintained at $85 \pm 1{ }^{\circ} \mathrm{C}$ for $24 \mathrm{~h}$ and cooled in a desiccator for $30 \mathrm{~min}$. The dried seedlings were weighed, and the mean was expressed as $\mathrm{mg} / 10$ seedlings. Seedling vigour index was calculated using the following formula as described by Abdul-Baki and Anderson (1973) and expressed in the whole number. Vigour index $=$ Germination percentage $\mathrm{x}$ Total seedling length in $\mathrm{cm}$. $\quad$...... Eq.2

Biochemical analysis of harvested seeds: Protein content was estimated by adopting the protocol of AliKhan and Youngs, 1973. The amount of amino acid in barnyard millet seed leachate was estimated in following the method described by Moore and Stein (1948), and the amount of sugar was analyzed as per the method of Somogyi (1952). The data was analyzed statistically adopting the procedure given by Panse and Sukhatme (1985).

\section{RESULTS AND DISCUSSION}

Foliar feeding of nutrients has become an established procedure in seed production to increase the seed yield and quality, and it also minimizes environmental pollution and improves nutrient utilization. (Abou-Elnour, 2002).

Sprout spray is an inexpensive and effective technology for improving the nutritional quality of cereals and 
grain legumes (Frias et al., 2005). Germination unfolds and enzymes trigger elaborate biochemical changes. Proteins break into amino acids. Water-soluble vitamins such as B complex and vitamin $C$ are created (Vidal-Valverde et al., 2002). Fats and carbohydrates are converted into simple sugars. Weight increases as the seed absorb water and minerals, sprouting induce biosynthesis of vitamin $\mathrm{C}$. Thiamin and Niacin are readily available through sprouts. Vitamin A content of seeds is improved considerably after sprouting. Germination increases the bioavailability of minerals and vitamins (Chingakham et al., 2015).

Thus, pulse sprouts are a sustainable source of nutrition owing to the rich nutrient content augmented upon sprouting and the considerably low cost of pulses such as horse gram and cowpea (Vega et al., 2010). Hence, it was hypothesized that application of the nutrient extract from the sprouted pulses in the form of foliar spray would enable better crop growth and productivity of rice (Jayanthi et al., 2013).

The present showed that the plant height was a direct index to assess the growth and vigour of the plant. Plant height of barnyard millet was found to increase slowly up to 60 DAS, thereafter it increased linearly up to 90 DAS, and it occurred at a diminishing rate under all irrigation regimes (Table.1). The increase in plant height by sprout extract spray might be due to bioactive substances like enzyme inhibitors, lectin and phenolic compounds (Vega et al., 2010). In addition, the readily available form of nutrients in foliar spray would assist the efficient absorption and subsequent transport enhancing growth parameters (Vijayalakshmi et al., 2019) in rice.

To achieve the highest yield, the total chlorophyll content must be higher (Table.2) to intercept more light energy and culminating in higher dry matter production (Renuka et al., 2007). Pulse sprout extract contains various enzymes like $\alpha$-amylase, phytase like compounds. It enhances the leaf chlorophyll content in plants and a reduction in chlorophyll degradation (Gomathi, 2011).

The present study indicated that pulse sprout extracts not only increased the vegetative growth of the plant but also triggered the early flowering and maturation in crops. Days to first flowering and $50 \%$ flowering were hastened in pulse sprout sprayed plants than the control in both the seasons. Between the seasons, the plants took a lesser number of days for first flowering in rabi, when compared to kharif, and this may be due to the seasonal effects in barnyard millet (Table.3).

The yield increase in pulse sprout extract sprayed plant are thought to be associated with the hormonal substances present in the extracts, especially cytokinins. Cytokinins in vegetative plant organs are associated with nutrient partitioning; whereas in reproductive

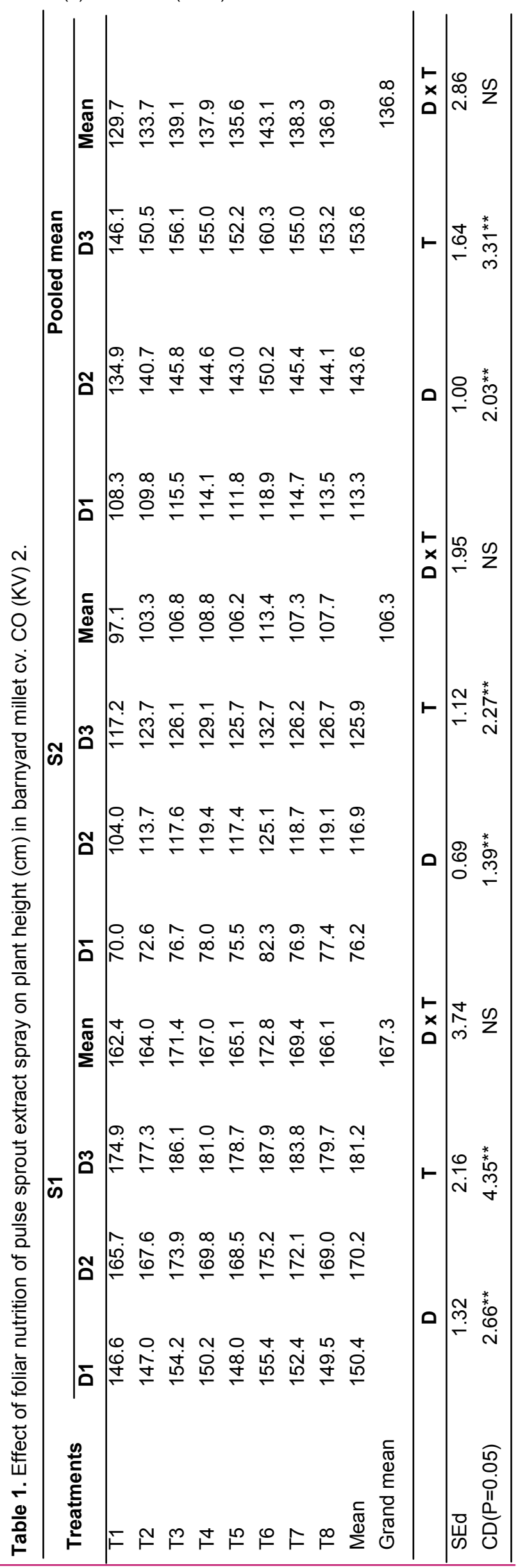


Kumar, N. N. et al. / J. Appl. \& Nat. Sci. 12(3): 394 - 400 (2020)

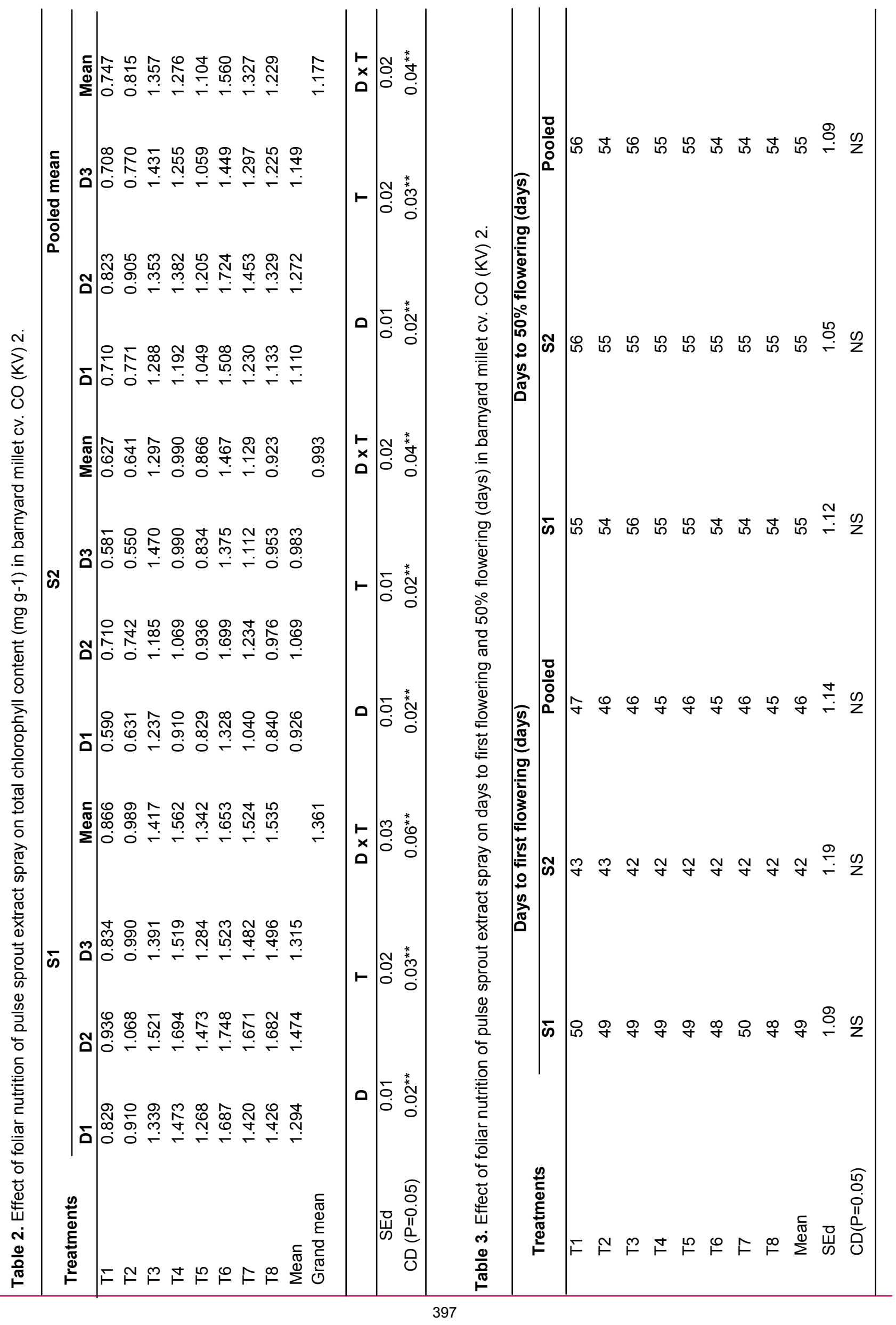


Kumar, N. N. et al. / J. Appl. \& Nat. Sci. 12(3): 394 - 400 (2020)

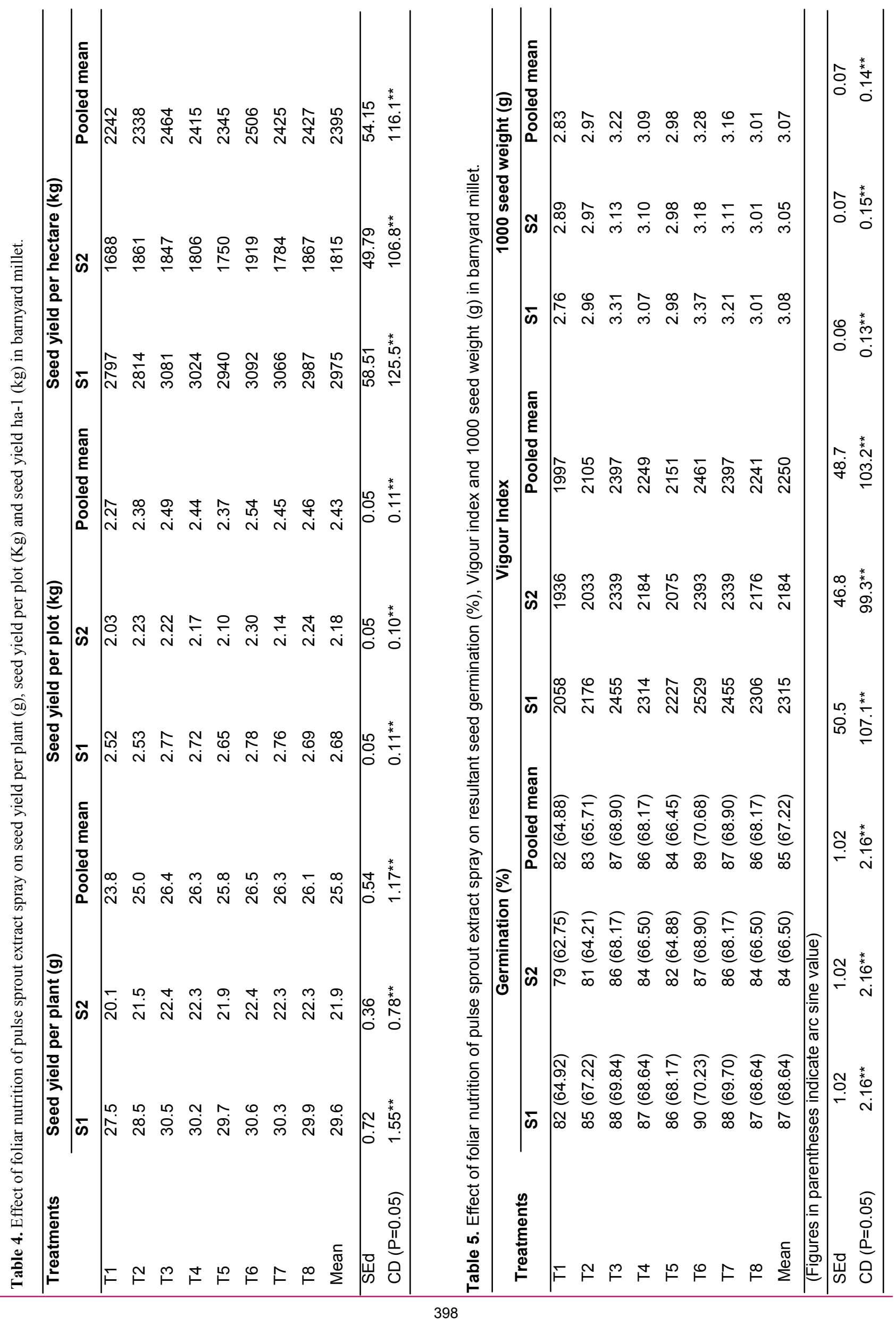


organs linked with nutrient mobilization (Zodape et al., 2008). Among the treatments, horse gram pulse sprout extract $2 \%$ foliar spray registered its superiority in both kharif and rabi seasons (Table.4). Increase in seed yield was mainly due to an increase in a number of productive tillers, panicle length and as well as 1000 seed weight (Vijayalakshmi et al., 2019) in rice. Yield enhancement effect due to improved chlorophyll content in leaves of various crop plants has been attributed to the phytase present in the pulse sprout extract (Vega et al., 2010).

The present study observed that spraying of pulse sprout extract on barnyard millet CO (KV) 2 in two stages viz., flowering and $50 \%$ flowering also improved the quality of resultant seeds, in terms of germination per cent, shoot length $(\mathrm{cm})$, root length $(\mathrm{cm})$ and vigour index. Pulse sprout extracts resultant seed recorded higher 1000 seed weight (g) compared to control in barnyard millet (Table 5). The protein content of the resultant seed of the crop sprayed with $2 \%$ horse gram pulse sprout extract was maximum (11.2\%) which was $19 \%$ higher compared to control, and the leachate amino acid and leachate sugars were minimum in the pooled analysis (Table 6).

Pulse sprouts are a rich source of enzymes, proteins and water-soluble vitamins (Vidal Valverde et al., 2002; Oloyo, 2003). Shinde and Bhilare (2003) have described that even if less amount of nutrients are added through foliage 2-3 times at different growth stages of crops was sufficient enough to satisfy the nutrient requirements of the crops with low-cost input. He also reported that foliar application of fertilizers was widespread among the agricultural crop production, as it seems to be more eco friendly in comparison with soil fertilization (Kuepper, 2003). Jaskulski (2007) has shown the positive economic effect of foliar fertilization in growing vegetables, having a direct impact on increasing yield.

\section{Conclusion}

The field experiments on the effect of pulse sprout spray through foliar spraying at a vegetative and flowering stage has proved that pulse sprout sprays irrespective of concentrations could improve the seed yield of Barnyard millet (E. frumentacea L.). However, the maximum improvement in seed yield and quality can be realized by spraying horse gram $2 \%$ extract. The yield enhancement may be due to the presence of bioactive substances in sprouted horse gram, and cowpea extracts were found effective towards yield aximization in barnyard millets.

\section{REFERENCES}

1. Abid, K., Zafar, H., Asad Ali, K., Junaid, A., Md Waseem, A., Haq, N. Farhan, A. and Kaleem, A. (2019). Effect of

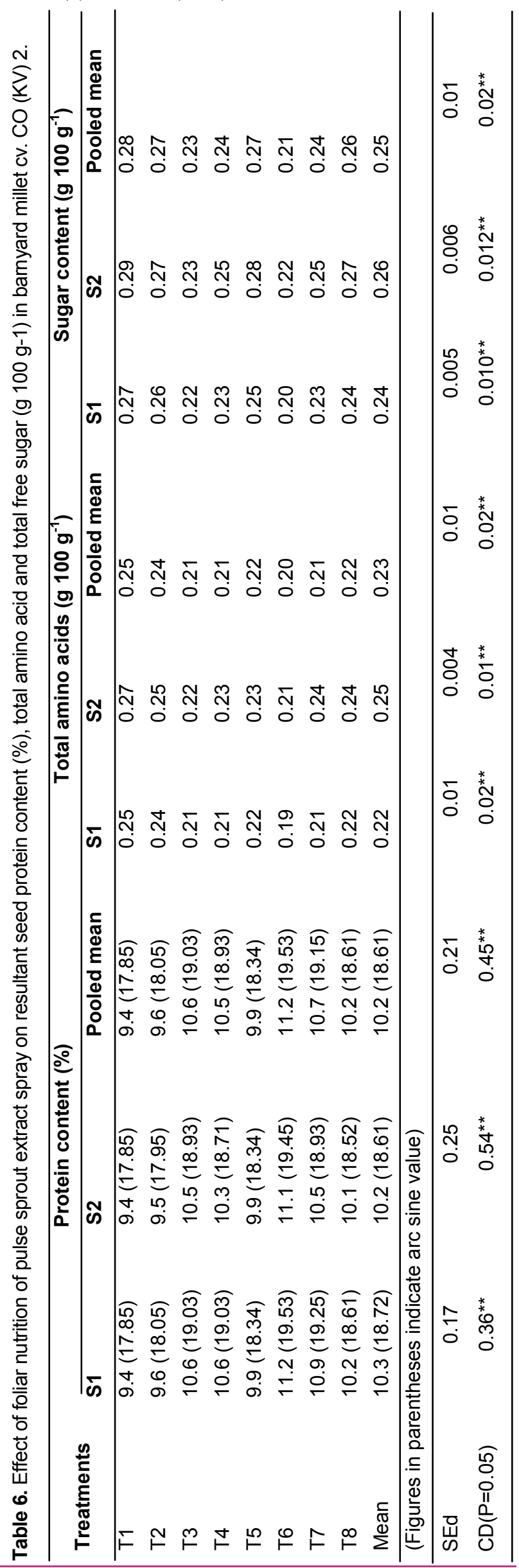


Foliar Application of Zinc and Boron on Growth and Yield Components of Wheat. Agri Res\& Tech: 21(1). 01-06.

2. Abou El-Nour, E. A. A. (2002). Can supplemented potassium foliar feeding reduce the recommended soil potassium? Pak. J. Biol. Sci. 5: 259-262.

3. Ali-Khan, S. T. and Young, C. G. (1973). Variation in protein content of field peas. Can. J. PI. Sci., 53: 37-41.

4. Anonymous. (1999). International Rules for Seed Testing. International Seed Testing Association. Seed Sci. \& Technol. 4: 3-177.

5. Arnon, D.L. (1949). Copper enzymes in isolated chloroplast polyphenoloxidase in Beta vulgaris. Plant Physiol., 24: $1-15$

6. Chingakham, B. D., Archana, K. and Anil, K. (2015). Sprouting characteristics and associated changes in nutritional composition of cowpea (Vigna unguiculata). J Food Sci Technol. 52(10):6821-6827.

7. Frias, J., Miranda, M. L., Doblado, R. and Vidal-Valverde, C. (2005). Effect of germination and fermentation on the antioxidant vitamin content and antioxidant capacity of Lupinus albus L. var Multolupa, Food Chemistry, 92: 211-220.

8. Geetharani, P., Manivannan, M.I. and Ponnuswamy, A.S. 2008. Seed production of onion as influenced by the application of growth regulators and nutrients. Aian J.of Hort. Vol. 3 (1): 301-303

9. Gomathi, M. (2011). Effect of seed and seed crop fortification technology with pulse sprout extract in greengram (Vigna radiata I.) and blackgram (Vigna mungo L.). M.Sc. (Ag.) Thesis, Tamil Nadu Agricultural University, Coimbatore.

10.Himanshu., K, Chauhan, M., Sonawane, S. K., Arya, S. S. (2018). Nutritional and Nutraceutical Properties of Millets: A Review. Clin. .J Nutr. Diet. 1(1):-10.

11.ISTA. 2012. International rules for seed testing. Bassersdorf (Switzerland): International Seed Testing Association.

12.Jaskulski, D. (2007). Comparison of the effect of foliar fertilization on economic and production effect of growing some field crops. Fragmenta Agronomica (Poland) 24 (93):106-112.

13.Jayanthi, M. (2008). Organic fortification of seed and seed crop of rice with pulse sprout extract (Oryza sativa L.). M. Sc. (Ag.) Thesis, Tamil Nadu Agricultural University, Coimbatore.

14.Jayanthi, M., Umarani, R and Vijayalakshmi, V. (2013). Effect of crop fortification with pulse sprout extract on crop growth and seed yield in rice var Co 48 . Scientific Res. \& Essays, 8(36): 1725-1729.

15.Kuepper, G. (2003). Foliar Fertilization Current Topic, ATTRA- National sustainable Agriculture Information service, NCAT Agriculture specialist. March Issue.

16.Moore, S. and W. H. Stein. (1948). Photochromic ninhydrin method for use in chromatography of amino acids. $J$. Biol. Chem., 176: 367-388.

17.Oloyo, R. A. (2003). Chemical and nutritional quality changes in germinating seeds of Cajanus cajan L. J. Food and Agrl. Chem., 85 (4): 497-502.
18.Panse, V. G., and Sukatme, P. V. (1985). Statistical methods for agricultural workers. New Delhi: ICAR publication.

19.Penas, E., Gomez, R., Frias, J., Vidal-Valverde. C. (2008). Application of high pressure on alfalfa (Medigo sativa) and mung bean (Vigna radiata) seeds to enhance the microbiological safety of their sprouts, Food Control (19): 698-705.

20.Renuka Bai, N., Laila Banu, N. R., Prakash, J. W. and Jaquilin Goldi. S. (2007). Effects of Asparagopsis taxiformis extract on the growth and yield of Phaseolus aureus. J. Basic and Applied Biol., 1(1): 6-11.

21.Saira, S. K., Adnan, Y., Adnan, R., Shahina, Y., Atif, R. (2011). Effect of Foliar Application of Macro and Micro Nutrients on Growth and Flowering of Gerbera jamesonii L. American-Euras. J. Agric. Environ. Sci. 11(5):736-757.

22.Sakthivel, S. (2010). Effect of seed fortification and foliar spray with pulse sprout extract on seed yield and quality of cotton (Gossypium sp.). M.Sc., (Ag.) Thesis, Tamil Nadu Agricultural University, Coimbatore.

23.Shinde, S. H. and Bhilare, R. L. (2003). Response of chickpea to soil and foliar application of DAP. Madras Agric. J., 90 (4-6): 352-354.

24.Somogyi, M. (1952). Note on sugar on delimitation. J. Biol. Chem., 200: 245-247.

25.Sujatha, K., Selvarani, K., Vijayalakshmi, V., Vanniarajan, C. and Sivasubramaniam.K. (2013). Seed fortification studies in barnyard millet (Echinochloa frumentacea) cv. CO1. J.of Agri. \& Veterinary Sci. 5(4): 22-24.

26.Veena, S., Chimmad, B. V., Naik, R. K. and Shanthakumar, G. (2005). Physico-chemical and nutritional studies in barnyard millet. Karnataka J. Agric. Sci., 18 (1): 101 -105 .

27.Vega, R. C., Loarca-Pina, G., Dave Oomah, B. (2010). Minor components of pulses and their potential impact on human health. Food Res. Intl., 48: 461-482.

28.Vidal-Valverde, C., Frías, J., Sierra, I., Blazquez, I., Lambien, F. and Kuo, Y. H.(2002). New functional legume food by germination. Effect on the nutritive value of beans, lentils and peas. European Food Research and Technology, 215: 472-476.

29.Vijayalakshmi, V. (2009). Effect of organic seed fortification and foliar spray with pulse sprout extract in rice seed crop (Oryza sativa L.). M.Sc., (Ag.) Thesis, Tamil Nadu Agricultural University, Coimbatore.

30.Vijayalakshmi, V., Umarani, R. and Jayanthi, M. (2019). Effect of organic foliar spray with pulse sprout extract on seed yield and quality of rice (Oryza sativa). J.of Plant nutrition, 42: 900-914.

31.Yoshida, S., Forno, A. A. and Cock, J. H. (1976). Laboratory manual for physiological studies of rice. Int. Rice Res. Institute, Philipines, pp. 36-37.

32.Zodape, S. T., Kawarkhe, V. J., Patolia, J. S. and Warade, A. D. (2008). Effect of liquid seaweed fertilizer on yield and quality of okra (Abelmoschus esculentus L.) J. Sci. Ind. Res., 67: 1115-1117. 